\title{
ANALISIS KEGIATAN CORPORATE SOCIAL RESPONSIBILITY TERHADAP RETURN SAHAM PADA INDUSTRI PERTAMBANGAN INDONESIA PADA PERIODE 2010-2016
}

\author{
Dinda Makhsya Septaulia ${ }^{1}$, Junino Jahja ${ }^{2}$ \\ ${ }^{1}$ Magister Manajemen, Fakultas Ekonomi dan Bisnis, Universitas Indonesia \\ Email: ninoj2@gmail.com \\ ${ }^{2}$ Magister Manajemen, Fakultas Ekonomi dan Bisnis, Universitas Indonesia \\ Email: adhiendinda@gmail.com
}

\begin{abstract}
ABSTRAK
Sejak CSR menjadi pusat perhatian dalam beberapa dekade terakhir, masyarakat maupun investor mengharapkan shareholders untuk bertindak lebih beretika dan socially responsible terhadap lingkungan. Tujuan dari penelitian ini adalah untuk menganalisis apakah dengan melakukan pengungkapan atas corporate social responsibility akan memberikan pengaruh terhadap return saham dari perusahaan. Penelitian ini menggunakan metode data panel dengan menggunakan software E Views Illustrated version 9, dengan data dari perusahaan tambang Indonesia yang telah mempublikasikan laporan keuangan dan/atau laporan keberlangsungan mulai dari tahun 2010 hingga tahun 2016. Sehingga jumlah observasi penelitian adalah 126 data. Dengan variable independen CSR disclosure, cash flow growth dan return on assets dari tiap perusahaan, semua variable ini diharapkan mampu menjelaskan apa pengaruhnya terhadap return saham pada sampel perusahaan yang digunakan dalam penelitian. Hasilnya menunjukkan bahwa CSR disclosure, cash flow growth dan return on assets perusahaan tidak memberikan pengaruh signifikan terhadap return saham.
\end{abstract}

Kata kunci: cash flow; corporate social responsibility; growth; mining industry; return on assets; stock return

\section{PENDAHULUAN}

Negara Indonesia sangat dikenal dengan hasil alam yang melimpah, mulai dari flora dan fauna yang beraneka ragam hingga hasil pertambangan yang bisa sangat banyak ditemukan tambangnya di seluruh wilayah Indonesia. Beberapa hasil tambang dari Indonesia diantaranya bauksit, nikel, emas, perak, batubara, bahkan berbagai macam jenis batu-batuan sangat banyak jumlahnya dan bisa digali di banyak wilayah di Indonesia. Jumlah produksi barang tambang di Indonesia yang kian meningkat menunjukkan bahwa industri pertambangan terus mengalami peningkatan tiap tahunnya (Badan Pusat Statistik, 2017).

Menjamurnya perusahaan tambang di Indonesia membuat pemerintah harus turun tangan, baik secara regional dan nasional, dalam mengatur kebijakan, standar dan kriteria berskala nasional untuk perusahaan-perusahaan tambang yang ada di Indonesia (Maimunah, 2016). Pemerintah harus berperan secara aktif dalam pengembangan, kontrol, evaluasi dan penyelesaian konflik yang mungkin terjadi dalam sektor pertambangan ini.

Di Indonesia sendiri hingga tahun 2012, belum ada peraturan tertulis yang mengharuskan perusahaan untuk menyatakan kegiatan sosial yang mereka lakukan ke dalam laporan keuangan perusahaan. Semua kegiatan sosial yang perusahaan lakukan pada tahun sebelum itu, yaitu tahun 2012, dilakukan secara sukarela. Hal ini terjadi karena melakukan kegiatan CSR dianggap bukan tujuan utama berdirinya suatu perusahaan sendiri. Perusahaan banyak beranggapan bahwa mereka tidak perlu lagi menjalankan kegiatan sosial guna menjamin sustain-nya perusahaan mereka, karena cukup dengan memenuhi kewajiban seperti membayar pajak kepada pemerintah. Hal ini diungkapkan oleh Friedman (1962) yang menyatakan: "pandangan seperti ini telah mendapat banyak reaksi positif penerimaan dari korporat, dimana memiliki tanggung jawab sosial yang melebihi dari keinginan pemangku kepentingan". 
Jika dilihat dari penjelasan di atas, bisa dilihat terdapat kesenjangan antara keinginan perusahaan untuk terus mensejahterahkan para pemegang sahamnya dengan keinginan para pemegang kepentingan termasuk masyarakat yang menuntut untuk diberi kemakmuran terhadap lingkungan mereka yang telah dirusak. Namun banyaknya penelitian yang memberikan bukti empiris bahwa perusahaan tidak akan merasa dirugikan dengan melakukan kegiatan sosial ini, membuat perusahaan diberikan alasan lebih kenapa mereka perlu untuk melakukan kegiatan tanggung jawab sosial ini. Dari penjelasan tersebut, penulis menyusun pertanyaan penelitian sebagai berikut:

1. Apakah kegiatan corporate social responsibility memiliki pengaruh terhadap return saham perusahaan pada industri pertambangan Indonesia?

2. Apakah cash flow growth memiliki pengaruh terhadap return saham perusahaan pada industri pertambangan Indonesia??

3. Apakah return on assets (ROA) memiliki pengaruh terhadap return saham perusahaan pada industri pertambangan Indonesia??

Dari analisis kesenjangan dan pertanyaan penelitian di atas, maka dirumuskan tujuan penelitian adalah untuk mengetahui, membuktikan dan menganalisis:

1. Pengaruh kegiatan corporate social responsibility terhadap return saham perusahaan yang berada pada industri pertambangan Indonesia.

2. Pengaruh cash flow growth terhadap return saham perusahaan yang berada pada industri pertambangan Indonesia.

3. Pengaruh Return on Assets (ROA) terhadap return saham perusahaan yang berada pada industri pertambangan Indonesia.

Motivasi penulis dalam melakukan penelitian ini adalah untuk melihat apakah fenomena mengenai "only invest in green companies" ini juga terjadi di Indonesia dan diharapkan dengan dilakukannya penelitian ini, perusahaan di Indonesia bisa menjadi lebih tertarik untuk lebih memperhatihan lingkungan atau dampak atas operasional perusahaan terhadap lingkungan karena bukan hanya berdampak baik bagi masyarakat dan lingkungan tetapi juga berdampak baik pada saham perusahaan itu sendiri, dilihat dari sisi return-nya.

\section{Landasan Teori}

Dasar dari terciptanya istilah tanggung jawab sosial dimulai dari adanya budaya. Bagaimana budaya itu terbentuk merupakan kombinasi dari pandangan suatu kelompok masyarakat atas nilai, kepercayaan dan hukum moralitas. Budaya inilah yang menjadi dasar pembentukan norma-norma yang tumbuh menjadi pedoman masyarakat dalam menjalankan hidup. Norma itu sendiri bisa berbeda-beda bergantung dengan bagaimana seseorang memandang kebebasan individual, demokrasi, keadilan sosial hingga rasa tanggung jawab akan sesuatu. Gabungan antara budaya dan etika dimana perusahaan tersebut berada yang nantinya akan membentuk sesuatu yang dinamakan tanggung jawab sosial perusahaan (corporate social responsibility). (Chatterji, 2017).

Pengungkapan CSR atau CSR disclosure yang dilakukan oleh perusahaan menyediakan informasi yang pada dasarnya tidak tersedia bagi pelaku pasar yang sumbernya tidak bisa didapat di tempat lain selain dari perusahaan itu sendiri (Klerk, de Villiers, van Staden, 2014). Perusahaan yang memenuhi tujuan moral dan sosial yaitu inti dari dilakukannya kegiatan sosial akan memberikan usaha yang lebih untuk menjalankan mekanisme dan mencapai actual beneficial outcomes dari perusahaan baik dari sisi sosial maupun ekonomi. Menciptakan keunggulan kompetitif bisa dilakukan dengan hal ini. Investor akan menganggap buruk (penalize) perusahaan yang memiliki environmental performers yang buruk namun hal ini tidak memberikan reaksi yang signifikan terhadap perusahaan yang environmental performers baik (Chan \& Milne, 1999). Setelah 
dikeluarkan Peraturan Pemerintah Kep-432/BL/2012 tahun 2012, perusahaan diwajibkan melakukan pengukapan kegiatan sosialnya dalam bentuk laporan. Meskipun terkait peraturan di atas, seharusnya perusahaan wajib untuk membuat pelaporan kegiatan sosial, namun masih terdapat beberapa perusahaan yang tidak melakukan csr disclosure dalam bentuk apapun. Oleh karena itu, hal ini akan dilihat dalam bentuk dummy variable, apakah perusahaan mengungkapkan kegiatan CSR-nya atau tidak, baik dalam bentuk annual report maupun sustainability report. Perusahaan yang melakukan CSR disclosure, nilainya adalah 1 dan perusahaan yang tidak melakukan CSR disclosure nilai adalah 0.

Berdasarkan penjelaskan di atas maka dibentuklah hipotesis 1 sebagai berikut:

H1: Kegiatan corporate social responsibility memiliki pengaruh terhadap return saham pada industri pertambangan Indonesia

Dalam buku Fundamentals of Financial Statement Brigham dan Houston (2004) dikatakan nilai dari sebuah asset atau keseluruhan dari perusahaan ditentukan dari seberapa besar arus kas yang bisa perusahaan hasilkan. Dikatakan pula bahwa meskipun pendapatan bersih perusahaan itu penting, namun arus kas perusahaan tidak boleh dilupakan karena dividen harus dibayar dalam bentuk kas dan kas juga dibutuhkan untuk membeli asset yang dibutuhkan agar perusahaan bisa terus beroperasi. Menurut Brigham dan Houston, tujuan dari perusahaan adalah untuk memaksimalkan harga dari saham perusahaan, karena nilai dari sebuah asset termasuk saham bergantung pada arus kas yang dihasilkan oleh asset, manajer harus berusaha memaksimalkan arus yang tersedia bagi investor dalam jangka panjang.

Berdasarkan penjelaskan di atas maka dibentuklah hipotesis 2 sebagai berikut:

H1: Cash flow growth memiliki pengaruh terhadap return saham pada industri pertambangan Indonesia

Tujuan yang serupa juga diungkapkan oleh Ross et al (2015) pada bukunya Corporate Finance, dimana tujuan dari financial management adalah untuk memaksimalkan nilai per saham dari setiap saham yang beredar. Untuk melakukan perhitungan pertumbuhan arus kas, penelitian ini menggunakan formula sebagai berikut:

$$
\text { Cash Flow Growth }=\frac{\text { Total Cash Flow }(\text { Tahun } t)-\text { Total Cash Flow }(\text { Tahun } t-1)}{\text { Total Cash Flow }(\text { Tahun } t-1)}
$$

Kegiatan CSR yang dinilai mengkonsumsi sejumlah besar sumber daya organisasi yang membuat beberapa perusahaan mungkin tidak bisa penuhi atau tidak ingin berinvestasi dalam hal itu (Torugsa Dan O'Donohue, 2012). untuk bisa mengimplementasikan CSR dengan sukses, perusahaan tidak hanya dituntut untuk menjaga struktur dan manajemen organisasi yang efektif namun juga mengalokasikan sumber daya untuk memotivasi dan mengkomunikasikan kepada karyawan secara efektif apa tujuan sebenarnya dilakukan kegiatan CSR.

Berdasarkan penjelaskan di atas maka dibentuklah hipotesis 3 sebagai berikut:

H1: Return on assets memiliki pengaruh terhadap return saham pada industri pertambangan Indonesia 
Pada setiap bagian balance sheet memiliki hubungan dengan income statement. Seperti pada bagian interest, ada kaitannya dengan long term debt dimana setiap utang yang ditanggung perusahaan memiliki bunga yang juga harus dilunasi ketika jatuh tempo. Pada bagian net income, dimana bagian ini akan berkaitan erat dengan jumlah equity yang terdapat pada balance sheet perusahaan. Lantas bagaimana dengan EBIT atau earning before interest and tax? Secara logika, EBIT erat kaitannya dengan asset perusahaan, sehingga akan lebih baik jika untung mengetahui seberapa baik perusahaan menggunakan assetnya untuk menghasilkan laba jika dibandingkan dengan nilai EBIT perusahaan (May, Yozzo \& Regan, 2001).

ROA merupakan bagian dari pengukuran pendapatan atau investment measurements dan bagaimana perusahaan memilih untuk membiayai investasinya seharusnya tidak relevan dengan kalkulasi terhadap return dari investasi tersebut. Net income merupakan return terhadap equityowners, oleh karena itu net income sepenuhnya milik shareholders perusahaan. Return on equity merupakan pengukuran rasio yang tepat jika ingin menggunakan net income dalam finantial ratio tersebut. Berdasarkan pernyataan di atas, maka dalam penelitian ini formula return on asset-nya adalah sebagai berikut:

$$
R O A=\frac{E B I T}{\text { Total Assets }}
$$

Berdasarkan penjelasan tiap variable dan penjabaran konseptual antar variable, maka didapatlah model penelitian sebagai berikut:

Y Return Saham $=\alpha+\beta_{1}$ CSR Disclosure $+\beta_{2}$ Growth $C F+\beta_{3} R O A+\varepsilon$

\section{METODE PENELITIAN}

Penelitian ini menganalisis apakah return saham dari perusahaan tambang Indonesia diperngaruhi oleh kegiatan corporate social responsibility. Untuk menjawab pertanyaan ini, sebuah studi empiris dilakukan, dengan melakukan pengukuran atas return saham berdasarkan beberapa faktor atau variabel tertentu yang telah dijelaskan sebelumnya. Data yang digunakan untuk penelitian ini adalah data sekunder, dimana data yang digunakan adalah annual report, laporan keuangan dan sustainability report dari masing-masing perusahaan tambang yang telah terdaftar di Bursa Efek Indonesia dan website lain untuk data tambahan demi keperluan penelitian ini. Jenis data tambahan yang digunakan adalah literatur seperti buku bacaan, jurnal dan artikel. Untuk penelitian ini dilakukan analisis mengenai bagaimana kinerja perusahaan sebelum dan sesudah adanya peraturan pemerintah mengenai kewajiban untuk melaporkan kegiatan CSR perusahaan, karena keterbatasan data pula sehingga pemilihan perusahaan yang digunakan sebagai sampel penelitian ini harus memiliki syarat sebagai berikut:

- Secara konsisten terdaftar di Bursa Efek Indonesia, perusahaan tambang yang termasuk dalam perusahaan tambang yang terhitung dari tahun 2010 hingga tahun 2016 atau selama periode 7 tahun.

- Annual report dan/atau sustainability report terbaru minimal pada 31 Desember 2016

Berdasarkan syarat-syarat sampel di atas, maka penelitian ini menggunakan data sampel sebanyak 18 perusahaan antara lain: Adaro Energy Tbk, Benakat Integra Tbk, Bumi Resources Tbk, Bayan Resources Tbk, Citatah Tbk, Darma Henwa Tbk, Delta Dunia Makmur Tbk, Elnusa Tbk, Energi Mega Persada Tbk, Harum Energy Tbk, Indo Tambangraya Megah Tbk, Medco 
Energi International Tbk, Perdana Karya Perkasa Tbk, Petrosea Tbk, Resource Alam Indonesia Tbk, Aneka Tambang Tbk, Bukit Asam Tbk, Timah Tbk.

\section{HASIL DAN PEMBAHASAN}

Penganalisisan data menggunakan program analisis data $e$ views illustrated versi 9. Data dalam penelitian ini termasuk dalam data panel, dimana data ini adalah gabungan antara cross section data dengan time series data. Data disusun dalam format excel dimulai dari satu perusahaan diikuti dengan periode tahun penelitian dan berikutnya data perusahaan selanjutnya berikut periode tahun penelitian dan begitu seterusnya. Sesuai dengan skema penelitian, analisis data dimulai dengan menentukan metode terbaik. Metode yang menjadi pilihan antara lain common effect, fixed effect dan random effect.

Berdasarkan hasil output pengolahan data, disimpulkan bahwa model terbaik untuk penelitian ini adalah metode Common Effect Model (CEM) didapatkan hasil sebagai berikut:

Tabel 1. Uji Chow

Sumber: Data diolah penelitian melalui E Views

\begin{tabular}{|l|r|r|r|}
\hline \multicolumn{1}{|c|}{ Effect Test } & \multicolumn{1}{c|}{ Statistic } & \multicolumn{1}{c|}{ d.f } & \multicolumn{1}{c|}{ Prob. } \\
\hline Cross-section F & 0,699667 & $(17,105)$ & 0,7969 \\
\hline Cross-section Chi-square & 13,521073 & 17 & 0,7007 \\
\hline
\end{tabular}

Dalam melakukan uji chow, H1 ditolak jika $p$-value $>\alpha(0,05)$ karena dalam hasil output di atas nilai $p$ value penelitian adalah 0,7969 maka $\mathrm{H} 0$ diterima yang berarti sejauh ini model terbaik menggunakan common effect model.

Setelah dilakukan uji chow, analisis data berlanjut pada uji hausman, dimana berdasarkan hasil output pengolahan data, disimpulkan bahwa metode terbaik untuk penelitian ini adalah model Random Effect Model (REM) didapatkan hasil sebagai berikut:

Tabel 2. Uji Hausman

Sumber: Data diolah penelitian melalui E Views

\begin{tabular}{|c|c|c|c|}
\hline Test Summary & Chi-Sq. Statistic & Chi-Sq. d.f & Prob. \\
\hline Cross-section random & 0,170625 & 3 & 0,9822 \\
\hline
\end{tabular}

Dalam melakukan uji hausman, $\mathrm{H} 0$ diterima jika $p$-value $>\alpha(0,05)$ karena dalam hasil output di atas nilai $p$ value penelitian adalah 0,9822, maka $\mathrm{H} 1$ diterima yang berarti model terbaik menggunakan Random Effect Model. Dari hasil output uji hausman di atas, maka diperoleh bahwa model penelitian terbaik sejauh ini adalah REM, namun untuk lebih memastikan dilakukan uji lagrange multiplier, maka yang diperolehlah output sebagai berikut:

Tabel 3. Uji Lagrange Multiplier

Sumber: Data diolah penelitian melalui E Views

\begin{tabular}{|c|c|c|c|}
\hline $\begin{array}{c}\text { Null (no rand.effect) } \\
\text { Alternative }\end{array}$ & $\begin{array}{c}\text { Cross-section } \\
\text { One-sided }\end{array}$ & $\begin{array}{c}\text { Period } \\
\text { One-sided }\end{array}$ & Both \\
\hline Breusch-Pagan & 0,902736 & 14,51019 & 15,41292 \\
& $(0,3420)$ & $(0,0001)$ & $(0,0001)$ \\
\hline
\end{tabular}


Dilihat dari hasil output di atas, dari kolom breusch-pagan maka bisa dipastikan bahwa model terbaik penelitian adalah Random Effect Model karena prob 0,00<0,05.

Setelah dilakukan pengujian berdasarkan uji model dan diperoleh model terbaik, kemudian dilakukan uji metode dan diperoleh metode mana yang terbaik, langkah selanjutnya adalah melakukan uji asumsi klasik. Yang pertama adalah uji normalitas. Uji normalitas dilakukan untuk mengetahui apakah distribusi data penelitian telah terdistribusi dengan normal atau tidak. Setelah dilakukan analisis data untuk uji normalitas maka diperoleh nilai jarque-bera 5285.463 dimana nilai ini jauh lebih besar daripada nilai chi square 23.68 maka data dikatakan tidak berdistribusi normal. Hal ini tidak menjadi masalah karena menurut Ghasemi dan Zahediasl (2012) mengatakan bahwa meskipun penting untuk memastikan bahwa data berdistribusi normal untuk mengetahui keakuratan data, namun dengan jumlah sampel penelitian ini lebih dari 30 yakni 126 sampel, maka normalitas data tidak menjadi masalah. Penelitian masih bisa melanjutkan me-regresi data namun dengan tidak keakuratan yang sama. Data yang digunakan sebagai sampel bisa saja tidak berdistribusi normal karena terdapat outlier atau interval datanya terlalu luas.

Uji asumsi klasik yang kedua adalah uji heterokedastisitas. Uji ini dilakukan untuk menilai apakah ada ketidaksamaan varian dari residual untuk pengamatan pada model regresi linear. Setelah dilakukan uji ini, diperoleh hasil sebagai berikut:

Tabel 4. Uji Heterokedastisitas

Sumber: Data diolah penelitian melalui E Views

\begin{tabular}{|c|c|c|c|}
\hline Test & Statistics & d.f & Prob. \\
\hline Breus-Pagan LM & 249,1032 & & 153 \\
\hline
\end{tabular}

Dalam uji heterokedastisitas ini, adapun hipotesis yang diuji adalah:

H0: Data mengandung heterokedastisitas, jika P-value $>\alpha(0,05)$

H1: Data homogen atau tidak mengandung heterokedastisitas, jika P-value $<\alpha(0,05)$

Dilihat dari output diatas maka disimpulkan bahwa data tidak mengandung heterokedastisitas atau data homogen karena nilai dari Breusch-Pagan adalah 0.00 atau lebih kecil dari 0,05.

Uji ketiga dalam uji asumsi klasik adalah uji multikolinearitas. Uji korelasi dilakukan untuk mengetahui apakah antar variable independen satu dengan yang lainnya memiliki hubungan. Bila antar variable terdapat hubungan, maka akan dicari seberapa kuat hubungan tersebut. Keeratan hubungan dinyatakan dalam bentuk koefisien korelasi. Setelah dilakukan pengujian ini, maka didapatlah hasil sebagai berikut:

Tabel 5. Uji Multikolinearitas

Sumber: Data diolah penelitian melalui E Views

\begin{tabular}{|cccc|}
\hline & CSR Disclosure & Cf Growth & Roa \\
\hline CSR Disclosure & 1,000000 & 0,091384 & $-0,085248$ \\
\hline Cf Growth & 0,091384 & 1,000000 & 0,022449 \\
\hline Roa & $-0,085248$ & 0,022449 & 1,000000 \\
\hline
\end{tabular}

Berdasarkan hasil uji di atas, untuk mengetahui apakah variable memiliki korelasi atau tidak adalah apakah data nilainya lebih kecil daripada 0,9 (Gozali, 2013), maka dikatakan tidak ada hubungan antar variable independen penelitian satu dengan variable independen lainnya karena semua variable nilainya $<0,9$. Uji multikolinearitas ini penting karena jika ada variabel 
independen yang ternyata saling berhubungan, maka salah satu dari variabel tersebut harus ada yang dihapus.

Setelah menentukan metode terbaik dan memastikan bahwa data penelitian telah lulus uji asumsi klasik, maka hal yang dilakukan selanjutnya adalah melihat berapa hasil persamaan regresi penelitian. Analisis pertama adalah melakukan analisis koefisien determinasi atau $R$-Square. Uji $\mathrm{R}^{2}$ digunakan pada model regresi berganda untuk mengetahui persentase kontribusi pengaruh variable independen secara serentak terhadap variable dependen. Setelah dilakukan regresi maka didapat hasil sebagai berikut:

Tabel 6. Nilai $R$ Square

Sumber: Data diolah penelitian melalui E Views

\begin{tabular}{|l|c|}
\hline R-squared & 0,023375 \\
\hline Adjusted R-squared & $-0,000641$ \\
\hline
\end{tabular}

Dari hasil di atas, nilai $R$-squared penelitian adalah 0,023 yang berarti variabel dependen dalam penelitian ini yaitu CSR disclosure, cash flow growth, dan Return on Assets mampu menjelaskan 2,3\% dari variabel dependen penelitian yaitu return saham. Ini terbilang sangat kecil karena banyak faktor lain yang mempengaruhi return dari suatu saham itu sendiri. Pada bab sebelumnya telah dijelaskan bahwa yang mempengaruhi harga saham ada dua yaitu resiko dan pertumbuhannya, faktor ini bisa dipengaruhi oleh faktor makroekonomi, seperti inflasi, tingkat suku bunga yang nantinya akan mempengaruhi harga saham yang nantinya berdampak pada return yang akan diperoleh para investor.

Widarjono (2013) menjelaskan bahwa semakin kecil nilai $R$-squared maka nilai variansi error-nya akan semakin besar. Dalam penelitian ini nilai sum squared resid atau variansi errornya adalah 364,1471. Nilai ini menggambarkan seberapa besar faktor yang tidak dijelaskan dalam model, nilai ini tergolong besar mengingat penelitian hanya menggunakan 3 variabel untuk menjelaskan variabel return saham. Nilai dari variansi error ini juga menggambarkan variansi data, yang artinya semakin besar variansi data dalam penelitian maka nilainya kaan semakin besar pula. Jika menilik kembali dari perusahaan sampel dan jenis produk yang dihasilkan bisa dilihat bahwa produk atau jenis perusahaan yang diteliti meskipun berada dalam satu industri yaitu industri pertambangan, namun tidak berarti variansi sampel tersebut homogen. Produk tiap perusahaan yang berbeda-beda dijelaskan dalam tabel di bawah ini:

Tabel 7. Jenis Pertambangan Perusahaan Sampel

Sumber: Data diolah penelitian melalui E Views

\begin{tabular}{|c|c|}
\hline Jenis Pertambangan & Nama Perusahaan \\
\hline Coal & ADRO, BUMI, BYAN, DEWA, ITMG, PTRO, PKPK, KKGI, PTBA \\
\hline Crude Petroleum dan Natural Gas & BIPI, ELSA, ENRG, MEDC \\
\hline Metal dan Mineral Mining & ANTM, TINS \\
\hline Stone & CTTH \\
\hline
\end{tabular}

Dari tabel di atas, jelas perbedaan jenis pertambangan dalam sampel penelitian yang menyebabkan tingginya nilai variansi error dan mengurangi nilai dari $R$-Squared penelitian ini.

Selanjutnya dilakukan analisis uji t. Dengan menggunakan level signifikansi 0,05, jika t hitung > $\mathrm{t}$ table, maka $\mathrm{H} 0$ ditolak dan jika t hitung < $\mathrm{t}$ table, maka $\mathrm{H} 0$ diterima. Dari hasil regresi penelitian maka didapat hasil sebagai berikut: 
Tabel 8. Hasil Uji $t$

Sumber: Data diolah penelitian melalui E Views

\begin{tabular}{|c|r|r|r|r|}
\hline Variable & \multicolumn{1}{|c|}{ Coefficient } & \multicolumn{1}{c|}{ Std. Error } & \multicolumn{1}{c|}{ t-Statistic } & \multicolumn{1}{c|}{ Prob. } \\
\hline CSR Disclosure & $-0,369223$ & 0,332499 & $-1,110448$ & 0,2690 \\
\hline CF Growth & 0,036992 & 0,047513 & 0,778549 & 0,4378 \\
\hline ROA & $-0,088937$ & 0,076689 & $-1,159701$ & 0,2484 \\
\hline C & 0,538005 & 0,195081 & 2,757855 & 0,0067 \\
\hline
\end{tabular}

Dengan menggunakan table t dilihat dengan nilai degree of freedom yang merupakan hasil dari pengurangan total sample (n) dengan jumlah variable (k) yang digunakan dalam penelitian. Sehingga nilai df adalah $18-4=14$. Kemudian dengan menggunakan nilai alpha 0,05 maka nilai $\mathrm{t}$ table penelitian adalah 2,145. Selanjutnya bisa dilakukan perumusan sebagai berikut:

- CSR Disclosure: -1,110 < 2,145, sehingga menerima H0, yang berarti csr disclosure tidak signifikan berpengaruh terhadap return saham. Hal ini bisa terjadi karena jika dilihat dari data sampel, tidak banyak dari perusahaan tambang yang menjadi sampel penelitian, yang melakukan pengungkapan dari kegiatan CSR-nya sebagai prioritas utama. Jika dilihat dari sisi investor pula, para investor tidak begitu mempedulikan apakah perusahaan telah melakukan kegiatan CSR atau tidak, terlepas dari trend SRI yang terjadi pada satu decade belakangan ini. Banyaknya investor yang menerapkan SRI cenderung melihat dalam jangka panjang dan karena keterbatasan data dalam penelitian ini pula hanya dilakukan penelitian selama 7 periode sedangkan efek dari dilakukannya CSR ini yang dipercaya memberikan efek sustainability belum bisa terlihat jika hanya menggunakan periode penelitian selama 7 tahun.

- Cash Flow Growth: 0,779 < 2,145, sehingga menerima H0, yang berarti cash flow growth tidak signifikan berpengaruh terhadap return saham. Pengelolaan dana dari operating cash flow tidak memberikan dampak akan kinerja perusahaan sedangkan jika dilihat dari variabel sebelumnya investor cenderung hanya memikirkan seberapa baik perusahaan mengelola resources-nya untuk kepentingan investor. Jika dilihat dari data yang diperoleh, nilai dari cash flow growth mayoritas negatif yang menunjukkan bahwa perusahaan sampel masih kurang baik dalam pengelolaan dana setidaknya selama periode yang menjadi tahun penelitian.

- Return on Assets: -1,160 > 2,145, sehingga menerima H0, yang berarti return on assets tidak signifikan berpengaruh terhadap return saham. Untuk variabel ini bisa dilihat pada lampiran 1 bahwa selama periode tahun penelitian masih banyak perusahaan tambang yang mengalami kerugian yang dilihat dari nilai EBIT (Earnings before Interest and Tax) yang masih banyak minus (-). Kegiatan CSR yang dilakukan oleh perusahaan juga tidak berdampak kepada perbaikan kinerja perusahaan, sehingga dalam hal ini tidak membuat masyarakat, investor atau konsumen membeli lebih banyak saham atau produk dari perusahaan tersebut. Tidak signifikannya ROA terhadap return saham bisa dipengaruhi oleh kurang efisiennya perusahaan dalam menggunakan assetnya dalam menghasilkan laba (Tamuntuan, 2015). Hal ini juga bisa didukung dengan banyaknya utang yang ditanggung oleh perusahaan demi memenuhi kebutuhan asset agar operasi perusahaan terus berjalan (Deloitte, 2014). Perusahaan tambang dikenal dengan perusahaan yang banyak mengandalkan utang untuk financing perusahaan, menjual asset untuk melunasi utang sudah bukan hal baru lagi, dengan semakin banyak asset yang dijual, kemampuan perusahaan untuk menghasilkan laba juga semakin berkurang.

Selanjutnya dari hasil regresi, maka model penelitian dirumuskan sebagai berikut: 


\section{$\mathrm{Y}$ Return Saham $=0,538-0,369$ CSR +0.0370 Growth $C F-0,0889 R O A+\varepsilon$}

Berdasarkan model penelitian di atas, maka bisa diinterpretasikan hasilnya sebagai berikut:

Dilihat dari nilai beta variabel CSR adalah $-0,369$ dan dengan nilai mediannya 0 maka banyak perusahaan yang cenderung tidak melakukan pengungkapan CSR. Dilihat dari hasil beta-nya, untuk setiap kenaikan 1 nilai pengungkapan CSR yang dilakukan perusahaan maka akan mengurangi return saham sebanyak 0,369. Hasil penelitian ini sesuai dengan penelitian yang dilakukan oleh Rusmanto dan William (2015) yang mengungkapkan bahwa perusahaan tambang Indonesia sejak dikeluarkannya Peraturan Pemerintah mengenai kewajiban mengungkapkan kegiatan CSR hanya 9\% dari total keseluruhan industri pertambangan yang melakukan pengungkapan ini. Meskipun pada kenyataannya mungkin perusahaan telah mengeluarkan biasa untuk kegiatan CSR ini.

Kegiatan CSR perusahaan tidak akan mengubah persepsi masyarakat apakah akan membeli atau tidak saham perusahaan tersebut yang nantinya akan berdampak pada return saham itu sendiri. Jika dilihat dari asal mula dikeluarkannya biaya untuk kegiatan CSR tersebut, dikarenakan asumsi perusahaan yang akan mendapatkan penerimaan lebih baik dari masyarakat. Hal ini berbeda dari persepsi investor yang menganggap jika perusahaan melakukan kegiatan CSR, maka biaya yang seharusnya bisa digunakan untuk memperbaiki kinerja perusahaan yang akan memberi benefit berupa pertumbuhan perusahaan akan berkurang. Hal ini akan mengurangi minat investor untuk membeli saham perusahaan tersebut dikarenakan fokus strategi perusahaan adalah untuk mendapat penerimaan dari masyarakat bukan mensejahterakan pemegang sahamnya, yang seharusnya menjadi fokus utama perusahaan.

Sebuah penelitian yang dilakukan oleh Ormiston \& Wong (2013) menunjukkan bahwa perusahaan yang berfokus untuk melakukan kegiatan yang bertanggung jawab secara sosial cenderung telah melakukan kegiataan yang tidak bertanggung jawab. Kecenderungan dalam melakukan kebagikan ini akan lebih vocally pronounced untuk menutupi irresponsible activities mereka. Perusahaan yang secara alamiah sudah memiliki image buruk di mata masyarakat contohnya seperti produsen rokok atau dalam penelitian ini perusahaan tambang yang notabene sangat merusak lingkungan (Bennett, 2015), perusahaan jenis ini sangat loyal mengeluarkan dana untuk kegiatan CSR, dikarenakan mereka ingin masyarakat menerima bisnis yang mereka jalankan. Ormitson dan Wong (2015) juga mengungkapkan bahwa secara kasar untuk setiap lima kegiatan CSR yang dilakukan oleh perusahaan, maka dapat menduga perusahaan telah melakukan satu kegiatan CSiR (Corporate Social Irresponsibility). Dapat disimpulkan bahwa perusahaan yang aktif dalam kegiatan CSR tidak selalu berarti mereka peduli akan keadaan masyarakat sekitar dan lingkungan, namun hal ini tidak bisa menjadi tolak ukur untuk semua industri.

Untuk nilai beta variabel cash flow growth yang berdasarkan hasil regresi yaitu 0,0370. Ini berarti dengan semakin perusahaan bertumbuh dilihat dari sisi cash flow-nya, maka akan memberikan dampak positif atau meningkatkan return saham perusahaan. Oleh karena itu, dengan kenaikan dari 1 nilai cash flow growth perusahaan akan memberikan dampak kenaikan return saham sebesar 0,0370. Dilihat dari nilai kolerasi antara cash flow growth dengan return saham yang senilai 0,059, maka korelasinya berpengaruh positif satu sama lain.

Dari sisi seorang investor, jika arus kas, dalam penelitian ini diambil arus kas yang berasal dari dana yang akan digunakan untuk kegiatan operasional perusahaan, maka return saham akan 
semakin meningkat. Arus kas, seperti telah dijelaskan sebelumnya, bisa digunakan untuk membiayai kegiatan perusahaan seperti operasional, investasi dan financing, dimana ketiga kegiatan ini sangat berpengaruh terhadap keseluruhan kinerja perusahaan. Pembayaran dividen juga lebih sering menggunakan kas, pembelian asset dan lain sebagainya. Ketika perusahaan memutuskan untuk menggunakan atau membagi uang tersebut untuk kegiatan CSR, maka kemungkinan bagi perusahaan untuk melakukan perbaikan kinerja perusahaan akan berkurang. Oleh karena itu, keputusan investor untuk berinvestasi terhadap perusahaan dengan arus kas yang tinggi masih berpengaruh positif, karena perusahaan tidak akan bisa beroperasi tanpa adanya kas (Sadeghi \& Askari, 2013).

Nilai beta dari variabel ROA yaitu -0,0889, maka semakin bertambahnya nilai ROA maka akan berdampak negatif pada return saham atau return saham akan semakin berkurang. Hal ini Jika dilihat dari nilai korelasi antara ROA dan return saham yang sebesar -0,096 maka korelasinya berdampak negatif satu sama lain. Oleh karena itu, untuk setiap 1 nilai kenaikan ROA, maka return saham akan mengalami penurunan sebesar 0,0089 .

Selama periode tahun penelitian, sampel perusahaan mayoritas mengalami kerugian dilihat dari nilai EBIT-nya yang cenderung negatif. Secara logika, jika nilai dari EBIT telah minus (-), maka nilai dari net income yang telah dikurangi dengan pajak dan bunga utang akan jauh lebih kecil lagi. Hal ini jelas mempengaruhi persepsi seorang investor ketika akan membeli saham perusahaan tersebut. Apakah perusahaan profit atau tidak, jika perusahaan tidak bisa menghasilkan laba dalam satu periode tertentu atau selama beberapa tahun terakhir sudah tidak menghasilkan laba lagi atau menghasilkan laba namun kenaikannya tidak signifikan, hal tersebut juga mempengaruhi persepsi investor akan return saham perusahaan tersebut. Dalam hasil penelitian, ROA yang memiliki hubungan negatif dengan return saham tidak bisa dijadikan salah satu faktor penentu apakah seorang investor akan berinvestasi pada saham perusahaan tersebut atau atau tidak (Jati, n.d.). Dari hasil uji t pun nilai ROA tidak menunjukkan signifikansi antara ROA dengan return saham. Kurangnya kemampuan perusahaan dalam menghasilkan laba secara efektif melalui jumlah asset yang dimiliki menjadi alasannya (Tamuntuan, 2015).

Berdasarkan hasil run e views yang telah dijelaskan di atas, maka berdasarkan hasil regresi variabel CSR disclosure yaitu -0,369 dan nilai uji t yaitu -1,110 dapat disimpulkan bahwa CSR disclosure memiliki pengaruh berlawanan dan tidak berpengaruh signifikan terhadap return saham. Untuk hasil regresi variabel cash flow growth yaitu 0,0370, disini nilainya positif yang menunjukkan bahwa variabel cash flow growth memiliki pengaruh searah terhadap return saham, namun nilai ini termasuk kecil. Kemungkinan besar tidak akan berpengaruh signifikan, pernyataan ini didukung dengan hasil uji t yaitu 0,779 dimana nilai ini lebih keci dari pada nilai t table dan nilai $p$-value 0,4378 yang nilainya lebih besar dari pada 0,05 yang berarti variabel cash flow growth tidak memiliki pengaruh signifikan terhadap return saham. Untuk nilai dari hasil regresi variabel return on assets yaitu -0,0889 dimana nilai ini negatif yang menunjukkan bahwa variabel ROA ini memiliki pengaruh berlawanan terhadap return saham. Dari hasil uji t ROA yaitu $-1,160$ yang nilainya jauh lebih kecil daripada t table yaitu 2,145, yang berarti variabel ROA tidak memiliki pengaruh signifikan terhadap return saham.

\section{KESIMPULAN DAN SARAN}

Tujuan dari penelitian ini telah dinyatakan pada bagian awal penelitian, yaitu menganalisis kesenjangan dan menjawab pertanyaan penelitian. Dalam prosesnya penelitian ini telah menggunakan banyak jurnal dan literatur yang membahas faktor apa saja yang bisa memberikan pengaruh terhadap harga saham suatu perusahaan dan penelitian ini juga membahas mengenai 
fenomena socially responsible investing (SRI) dimana ada sekelompok investor yang hanya ingin berinvestasi pada green companies. Setelah dilakukan analisis data maka diperolehlah kesimpulan sebagai berikut:

1. Corporate social responsibility (CSR disclosure) tidak berpengaruh signifikan terhadap return saham perusahaan yang berada pada industri pertambangan Indonesia. Sudut pandang investor yang masih menganggap bahwa biaya untuk kegiatan CSR tidak lain hanyalah sebagai expense atau membuang resources (Freeman \& McVea, 2001) membentuk persepsi bahwa perusahaan tidak menjadikan investor prioritas utama (Ormiston \& Wong, 2013). Sehingga cenderung tidak membeli saham perusahaan tersebut, yang nantinya akan mempengaruhi demand akan sahamnya yang menyebabkan turunnya harga saham berakibat pada return saham sendiri.

2. Cash flow growth tidak berpengaruh signifikan terhadap return saham perusahaan yang berada pada industri pertambangan Indonesia. Meskipun growth cash flow berpengaruh positif terhadap return saham namun nilainya yang kecil tidak memungkinkan bagi variabel ini udah berpengaruh signifikan terhadap return saham. Hal ini menunjukkan bahwa ketika investor memilih suatu perusahaan (khususnya perusahaan yang termasuk dalam sampel penelitian) sebagai saham yang akan diinvestasikan bukan dikarenakan pertumbuhan arus kas perusahaan tersebut (Armstrong, Barth, Jagolinzer, \& Riedl, 2010).

3. Return on Assets (ROA) tidak berpengaruh signifikan terhadap return saham perusahaan yang berada pada industri pertambangan Indonesia. Perusahaan sampel tidak bisa memaksimalkan penggunaan assets yang dimiliki untuk memperoleh laba. Dilihat dari data nilai EBIT yang mayoritas negatif menunjukkan bahwa perusahaan masih merugi. Investor tentu menganggap bahwa perusahaan ini tidak akan bisa memberikan yang menjadi tujuan utama perusahaan melakukan investasi yaitu dividen dan capital gain (Bodie, Kane, 2009).

Dari ketiga variabel tersebut maka dapat disimpulkan bahwa return saham, yang nilainya didapat dari perubahan harga saham dari satu periode (monthly) dengan periode sebelumnya, tidak ditentukan oleh faktor fundamental tetapi berdasarkan demand dan supply dalam pasar yang bersifat spekulatif. Hal ini sesuai dengan penelitian yang dilakukan oleh Djamaluddin, Rahmawati, \& Hapziali (2017) dan Tamuunu \& Rumokoy (2014).

Dalam penelitian ini, terdapat beberapa kekurangan yang membuat penelitian ini masih memiliki beberapa keterbatasan antara lain:

1. Sampel penelitian hanya perusahaan tambah yang telah go public setelah tahun 2010

2. Jumlah sampel penelitian hanya 18 perusahaan tambang saja

3. Periode yang dipilih untuk penelitian hanya 7 tahun dari 2010 hingga 2016.

4. Model penelitian terbatas hanya pada variabel return saham yang dipengaruhi oleh kegiatan CSR dan beberapa variabel kontrol.

Berdasarkan permasalahan dan batasan penelitian yang telah disebutkan di atas, maka saran penelitian adalah sebagai berikut:

1. Bagi Instansi/Perusahaan dalam Industri Pertambangan Indonesia

Berdasarkan hasil penelitian ini, perusahaan tidak bisa mengandalkan faktor fundamental dan kegiatan CSR untuk meningkatkan return saham. Sehingga disarankan fokus untuk menambah minat investor untuk meningkatkan jumlah demand pembelian saham perusahaan.

2. Bagi Akademis/Teoritis 
Untuk peneliti selanjutnya, bisa menambahkan variabel lain untuk menjelaskan return saham. Contohnya menggunakan variabel makroekonomi perusahaan seperti inflasi, interest rate, exchange rate (Benaković \& Posedel, 2012) atau variabel mikro perusahaan seperti struktur finansial perusahaan dan profitability rasio (Er \& Vuran, 2012). Untuk variable terkait trend SRI bisa diganti dengan faktor lain yang mungkin mempengaruhi pemilihan investor atas saham yang menjadi pilihan investasinya, contohnya dengan membandingkan portfolio saham yang memiliki kinerja sosial yang tinggi dengan yang rendah (Tamošiūnienè \& Slapikaitė, 2012).

Diharapkan untuk memperbanyak jumlah sampel penelitian menggunakan industri yang lebih sensitif terhadap keadaan lingkungan seperti industri agrikultur dan transportasi udara (Vargas, 2016). Ada baiknya peneliti selanjutnya meninjau kembali industri atau perusahaan seperti apa yang akan dijadikan sampel penelitian.

\section{REFERENSI}

Armstrong, C., Barth, M. E., Jagolinzer, A. D., \& Riedl, E. J. (2010). Market Reaction to Events Surrounding the Adoption of IFRS in Europe Market Reaction to Events Surrounding the Adoption of IFRS in Europe. The Accounting Review, 85(1), 31-61. https://doi.org/10.2307/27784261

Badan Pusat Statistik. 2017. "Produksi Barang Mineral, 1996-2015". https://www.bps.go.id/linkTableDinamis/view/id/1126 diakses 27 Januari 2017.

Benaković, D., \& Posedel, P. (2012). Do macroeconomic factors matter for stock returns? Evidence from estimating a multifactor model on the Croatian market. Business Systems Research, 1(1), 39-46. https://doi.org/10.2478/v10305-012-0023-z

Brigham E. Houston J.F. (2004). Fundamental of Financial Management. $10^{\text {th }}$ edition. Thomson. South Western.

Chan, C. C. C., \& Milne, M. J. (1999). Investor reactions to corporate environmental saints and sinners: an experimental analysis. Accounting and Business Research, 29(4), 265-279. https://doi.org/10.1080/00014788.1999.9729588

Chatterji, M. (2017). Integral Ecology and Sustainable Business. https://doi.org/10.1108/S15728323201726

Deloitte. (2014). Tracking the trends 2014: The 10 top issues mining companies will face in the coming year, 1-44. Retrieved from https://www2.deloitte.com/content/dam/Deloitte/global/Documents/Energy-and-

Resources/gx-er-tracking-the-trends-2016.pdf

Djamaluddin, P. S., Rahmawati, D., \& Hapziali, P. (2017). The Influence of Fundamental Factors Micro and Macro to Return Expected Through The Intervening Corporate Value in The Listed Real Estate Sector in Bei Periode 2011-2014, 6(2), 14-22.

Er, Ş., \& Vuran, B. (2012). Factors Affecting Stock Returns of FirmsQuoted in ISE Market: A Dynamic Panel Data Approach. International Journal of Business and Social Research, 2(1), 109-122. Retrieved

from http://www.thejournalofbusiness.org/index.php/site/article/view/209/208

Freeman, R. E., \& McVea, J. (2001). Darden Graduate School of Business Administration A Stakeholder Approach to Strategic Management. Working Paper, (1). https://doi.org/10.2139/ssrn.263511

Jati, I. K. (n.d.). PENGARUH RASIO KEUANGAN TERHADAP RETURN SAHAM UNGGULAN YANG TERDAFTAR DI BURSA EFEK INDONESIA, 1-18.

Maimunah, S. (2016). Gender \& Mining in Indonesia :, (May).

Ormiston, M. E., \& Wong, E. M. (2013). License to Ill: The effects of corporate social 
responsibility and ceo moral identity on corporate social irresponsibility. Personnel Psychology, 66(4), 861-893. https://doi.org/10.1111/peps.12029

Ross. Stephen A. dkk. (2015). Corporate Finance Asia Global Edition. Penn Plaza, New York. McGraw-Hill Education.

Sadeghi, Z., \& Askari, S. A. (2013). Cash Flow , Earning Opacity and its Impact on Stock Price Crash Risk in Tehran Stock Exchange, 3(4), 138-145. https://doi.org/10.6007/IJARAFMS/v3-i4/385

Tamošiūnienè, R., \& Slapikaite, I. (2012). The Effect of Socially Responsible Investing on Portfolio Performance. The 7th International Scientific Conference "Business and Management 2012, (September 2005). https://doi.org/10.3846/bm.2012.030

Tamuntuan, U. (2015). Analysing the Effect of Roe Roa and Eps Toword Share Price an Empirical Study of Food and Beverage Companies Listed on Indonesia Isx, 15(5), 446-457.

Tamuunu, S. C., \& Rumokoy, F. (2014). The influence of fundamental factors on stock return (Case study: Company Listed in LQ45 2011-2014). Journal of Marketing Research, 3(4).

Vargas, L. (2016). Corporate Social Responsibility and Financial Performance: GIC's Share Prices Value Impact - Event Study, 10, 165-177. https://doi.org/10.1108/S2043052320160000010012 